\title{
Giant pericallosal lipoma associated with intractable epilepsy in a child
}

\author{
Kavya Rao, ${ }^{1}$ Michael L Levy, ${ }^{2}$ John Ross Crawford ${ }^{3}$
}

${ }^{1}$ School of Medicine, University of California San Diego, La Jolla, California, USA

${ }^{2}$ Department of Neurosurgery, University of California San Diego, San Diego, California, USA

${ }^{3}$ Department of Neurosciences and Pediatrics, University of California San Diego, San Diego, California, USA

\section{Correspondence to}

Dr John Ross Crawford, jrcrawford@ucsd.edu

Accepted 14 October 2014

\section{DESCRIPTION}

An 18-month-old girl first presented with afebrile seizures in the setting of a non-focal neurological examination and diffuse frontal slowing on EEG. MRI revealed a giant $\mathrm{T} 1$ hyperintense homogenous mass lesion along the interhemispheric fissure and pericallosal region consistent with a lipoma. The pericallosal lipoma is associated with dysgenesis of the corpus callosum and colpocephaly (figure 1). Twelve years after initial diagnosis the child has medically intractable epilepsy on three anticonvulsants without significant change in lipoma size or appearance on serial MRI examinations. Our patient continues to be medically managed at this time given the tumour's extensive vascular supply, which includes the pericallosal artery arising from the anterior cerebral artery.

Central nervous system (CNS) lipomas represent $0.5-1 \%$ of brain tumours and are most frequently located in the interhemispheric fissure and the quadrigeminal cistern. ${ }^{1}{ }^{2}$ Fifty per cent are asymptomatic at the time of discovery, while others may present with headaches and seizures. ${ }^{3}$ CNS lipomas have low attenuation on CT and homogenously high signal without enhancement on T1-weighted MRI. CNS lipomas are often slow growing, have an excellent prognosis and are often only observed. Surgical excision is generally considered only in those patients who have refractory epilepsy attributable to the lipoma. ${ }^{1}$ The tumour size, vascular supply and ictal location of seizures are all important factors for determining candidacy for epilepsy surgery. Owing to its relative rarity, the precise incidence of intractable epilepsy in association with pericallosal lipomas is not entirely known and worthy of further study.

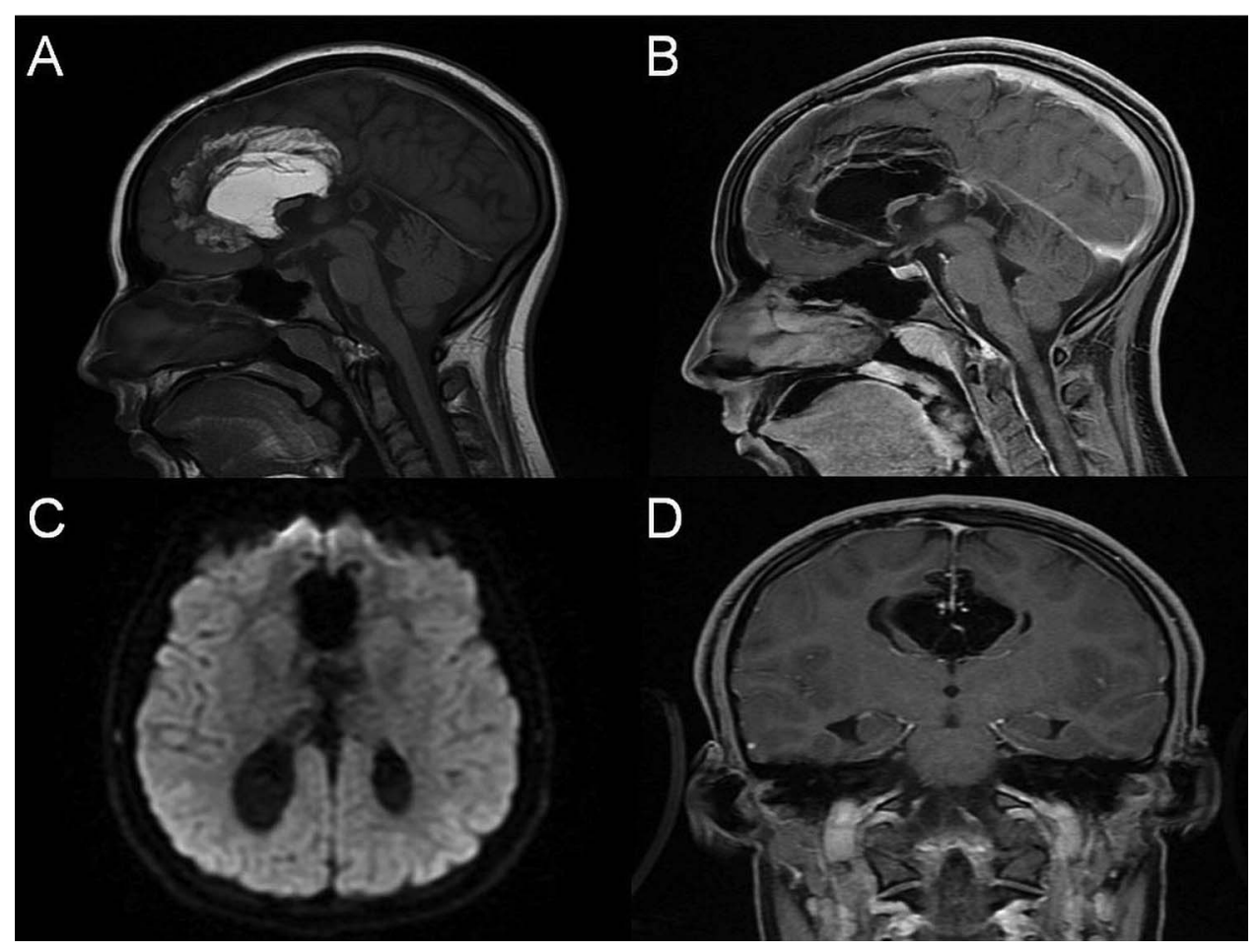

To cite: Rao K, Levy ML, Ross Crawford J. BMJ Case Rep Published online: [please include Day Month Yearl doi:10.1136/bcr-2014205403
Figure 1 Neuroimaging features of giant pericallosal lipoma. Pregadolinium sagittal T1-weighted MRI reveals a homogenous, hyperintense mass and significant dysgenesis of the corpus callosum (A). The tumour is highly vascular and includes a pericallosal branch off of the anterior circulating artery, visualised on postgadolinium sagittal (B) and coronal (D) MRI. There is colpocephaly present such that the occipital horns of the lateral ventricles are disproportionately dilated compared with the frontal horns, visible on diffusion-weighted imaging axial MRI (C). 


\section{Learning points}

- Agenesis of the corpus callosum and other structural abnormalities are commonly seen in association with pericallosal central nervous system (CNS) lipomas.

- The majority of pericallosal lipomas present as an incidental finding and often require no surgical or adjuvant therapies.

- Pericallosal CNS lipoma may be associated with intractable epilepsy and, depending on the size, location and vascularity, patients may be potential surgical candidates.
Competing interests None.

Patient consent Obtained.

Provenance and peer review Not commissioned; externally peer reviewed.

\section{REFERENCES}

1 Yilmaz N, Unal O, Kiymaz N, et al. Intracranial lipomas-a clinical study. Clin Neurol Neurosurg 2006;108:363-8.

2 Gomez-Gosalvez FA, Menor-Serrano F, Tellez de Meneses-Lorenzo M, et al. Intracranial lipomas in paediatrics: a retrospective study of 20 patients. Rev Neurol 2003;37:515-21.

3 Davutoglu M, Yesil Y, Asan A, et al. Non-febrile seizure associated with pericallosal lipoma. Pediatr Neonatol 2008;49:245-7.

Copyright 2014 BMJ Publishing Group. All rights reserved. For permission to reuse any of this content visit http://group.bmj.com/group/rights-licensing/permissions.

BMJ Case Report Fellows may re-use this article for personal use and teaching without any further permission.

Become a Fellow of BMJ Case Reports today and you can:

- Submit as many cases as you like

- Enjoy fast sympathetic peer review and rapid publication of accepted articles

- Access all the published articles

- Re-use any of the published material for personal use and teaching without further permission

For information on Institutional Fellowships contact consortiasales@bmjgroup.com

Visit casereports.bmj.com for more articles like this and to become a Fellow 